\title{
PERENCANAAN DAN PERANCANGAN PASAR LKMK SEMOLOWARU, SURABAYA DENGAN KONSEP MODERN
}

\author{
Oleh : Anak Agung Sagung Alit Widyastuty *)
}

\begin{abstract}
Abstrak
Fenomena yang terjadi sekarang ini di kota - kota besar banyak berkembang pasar pasar modern seperti minimarket, hipermartket, mall - mall yang lama kelamaan menggeser keberadaan pasar trasidional. Masyarakat lebih senang berbelanja di pasar Modern dikarenakan pasar modern lebih nyaman, bersih, dan dingin.

Tujuan Penelitian ini adalah untuk mengantisipasi agar keberadaan pasar tradisional tidak tergeser perannya dalam menyumbangkan anggaran pendapatan daerah juga pendapatan penduduk sekitar. Untuk itu pasar tradisional perlu dikembangkan dengan mengambil konsep dari pasar modern. Dengan tidak meninggalkan ciri khas pasar tradisional berupa harga murah, dan terjadi interaksi tawar menawar harga, pembeli dan pedagang dapat menikmati ruangan pasar yang nyaman, bersih dan segar tetap harus dipertahankan. Konsep pasar modern yang di ambil adalah system penataan ruang pasar serta sirkulasi aktivitas penghuni pasar.

Penelitian ini merupakan penelitian dengan pendekatan Deskriptif Kualitatif, penjabaran tentang karakteristik pedagang dan pembeli, aktivitas pasar berupa rotasi pasar, arus barang dan jasa serta tingkat persaingan pedagang dan juga ruang pasar. Populasi yang diteliti adalah para pedagang dan pembeli yang ada di Pasar LKMK Semolowaru, sampel yang di ambil sebanyak 96 pedagang dan pembeli. Metode pengumpulan data dengan observasi, penyebaran kuisioner dan kompilasi dari beberapa literature pendukung analisis. Analisis yang digunakan menggunakan analisis Deskriptif Kualitatif berupa analisis karakteristik pedagang dan pembeli, analisis aktivitas pasar, dan analisis ruang pasar

Kesimpulan dari penelitian dilihat dari karakteristik pedangan dan pembeli sebagian besar berada di lingkungan kecamatan Semolowaru. Aktivitas pasar belum optimal dan mengenai ruang pasar, masih banyak ruang pasar yang belum di pergunakan dan banyak fasilitas pasar yang tidak terawat. Hasil dari penelitian ini adalah memberikan rekomendasi berupa konsep perencanaan dan penataan pasar tradisional yang nantinya dapat dinikmati oleh semua tidak hanya kalangan ibu rumah tangga kalangan menengah kebawah juga untuk kalangan muda maupun kalangan anak - anak. Keberadaan pasar tradisional ini akan tetap eksis ditengah - tengah maraknya pembangunan pasar - pasar modern.
\end{abstract}

Kata kunci : perancangan, pasar tradisional, konsep pasar modern, pasar LKMK Semolowaru.

\section{PENDAHULUAN}

Pasar Tradisional merupakan salah satu warisan budaya yang perlu dilestarikan. Dalam beberapa prasasti menyebutkan bahwa pasar tradisonal di masa Jawa kuno telah terbangun sebuah sistem berdasarkan kosmologi yang dianut dan dipercaya oleh masyarakat Jawa kuno. Dalam Prasasti Pangumulan A yang berangka 824 Saka (902 M) dijelaskan mengenai adanya orangorang yang datang dari satu desa ke desa lain untuk berdagang pada hari-hari pasar. Dengan demikian, pada hari pasar, para pedagang dari desa itu sendiri maupun desa-desa di sekitar pasar membawa dagangan mereka ke pasar.

Selain memiliki keunggulan yang dimiliki pasar tradisional, tidak dapat dipungkiri bahwa pada umumnya pasar tradisional juga memiliki kelemahan yang kini kian terlihat semakin semrawut. Kendala pasar tradisional yang ada di Indonesia dilihat dari segi fisik, permasalahan yang ada yaitu (Kompas, 2007) Pasar tradisional belum dapat dibebaskan dari citra negatif sebagai tempat yang kumuh, semrawut, becek, kotor, dan bau serta penataan los/kios/lapak yang tidak beraturan.

Dari fakta di atas, dapat disimpulkan bahwa masalah kinerja pasar tradisional lebih dipengaruhi oleh faktor fisik yakni kebersihan dan kenyamanan. Aspek ini terkait dengan karakteritik pelaku pasar dalam memanfaatkan ruang pasar, terutama para pedagang. Sehingga ke depannya akan tercipta sebuah konsep dengan suasana pasar yang nyaman, aman dan bersih.

*) Dosen Perencanaan Wilayah dan Kota (PWK) Universitas PGRI Adi Buana Surabaya 
Pasar Semolowaru menjadi istimewa karena merupakan salah satu pasar tradisional yang masih dikelola oleh Lembaga Kemasyarakatan setempat yaitu LKMK Semolowaru. Sehingga "Sense of Beloging" dari masyarakat setempat terhadap keberadaan pasar sangat besar.

Pasar LKMK merupakan salah satu pasar tradisional yang masih diminati oleh warga sekitar Surabaya, berada di kecamatan Sukolilo. Lokasi yang strategis menjadikan pasar ini tetap "exis" (dalam arti "bertahan dan selalu dikunjungi") diantara beberapa pasar tradisional di wilayah Surabaya yang lain. Aktifitas pasar Semolowaru dimulai sejak subuh, beraneka macam sayuran segar, buah-buahan dan kebutuhan pokok lainnya diperjualbelikan. Harga yang relatif murah dan kualitas yang bagus menjadi pilihan bagi ibu-ibu, anak kost maupun pedagang kaki lima untuk berbelanja di pasar ini. Pukul 06.00 - 12.00 merupakan waktu tersibuk di Pasar LKMK. Setelah waktu sibuk diatas jam 12.00 wib, pasar LKMK Semolowaru tidak ada kegiatan apapun.

Banyak sekali kekurangan dalam hal penataan di Pasar LKMK Semolowaru. Tidak adanya saluran Drainase, pengolahan Sampah sisa pasar, dan pemetaan kios kios pasar, sehingga perlu adanya pemikiran ke depan untuk memajukan pasar LKMK Semolowaru ini.

Dengan permasalahan diatas, maka akan sangat menarik untuk dibahas mengenai konsep Perencanaan dan Penataan ruang pasar tradisional dengan konsep modern di Pasar LKMK Semolowaru. Jadi, rumusan masalah dalam studi penelitian ini adalah seperti apakah konsep perencanaan dan penataan ruang pasar tradisional dengan konsep Modern.

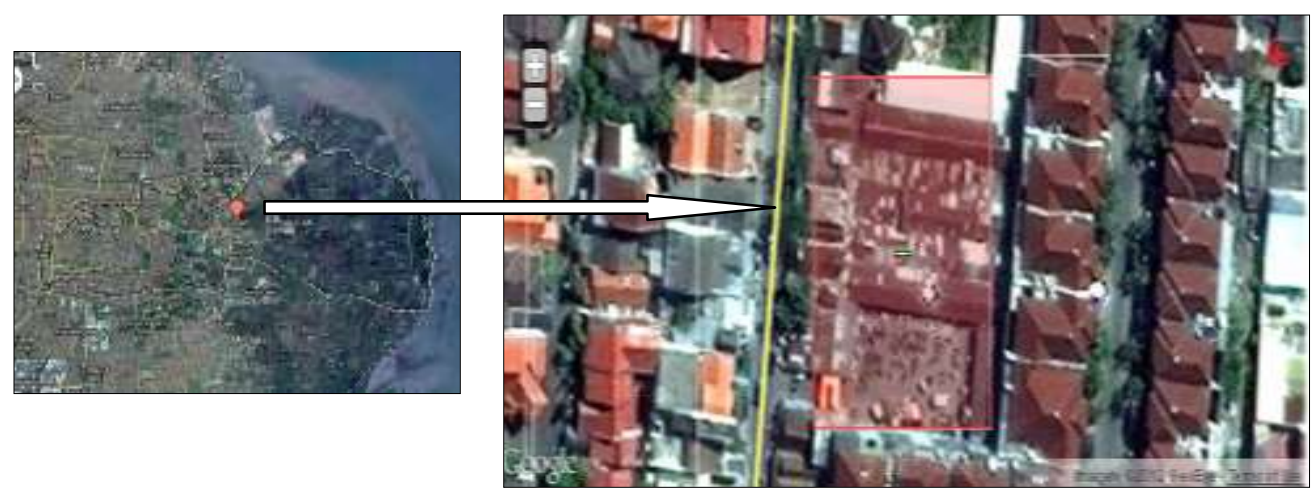

Gambar 1. Lokasi pasar LKMK Semolowaru

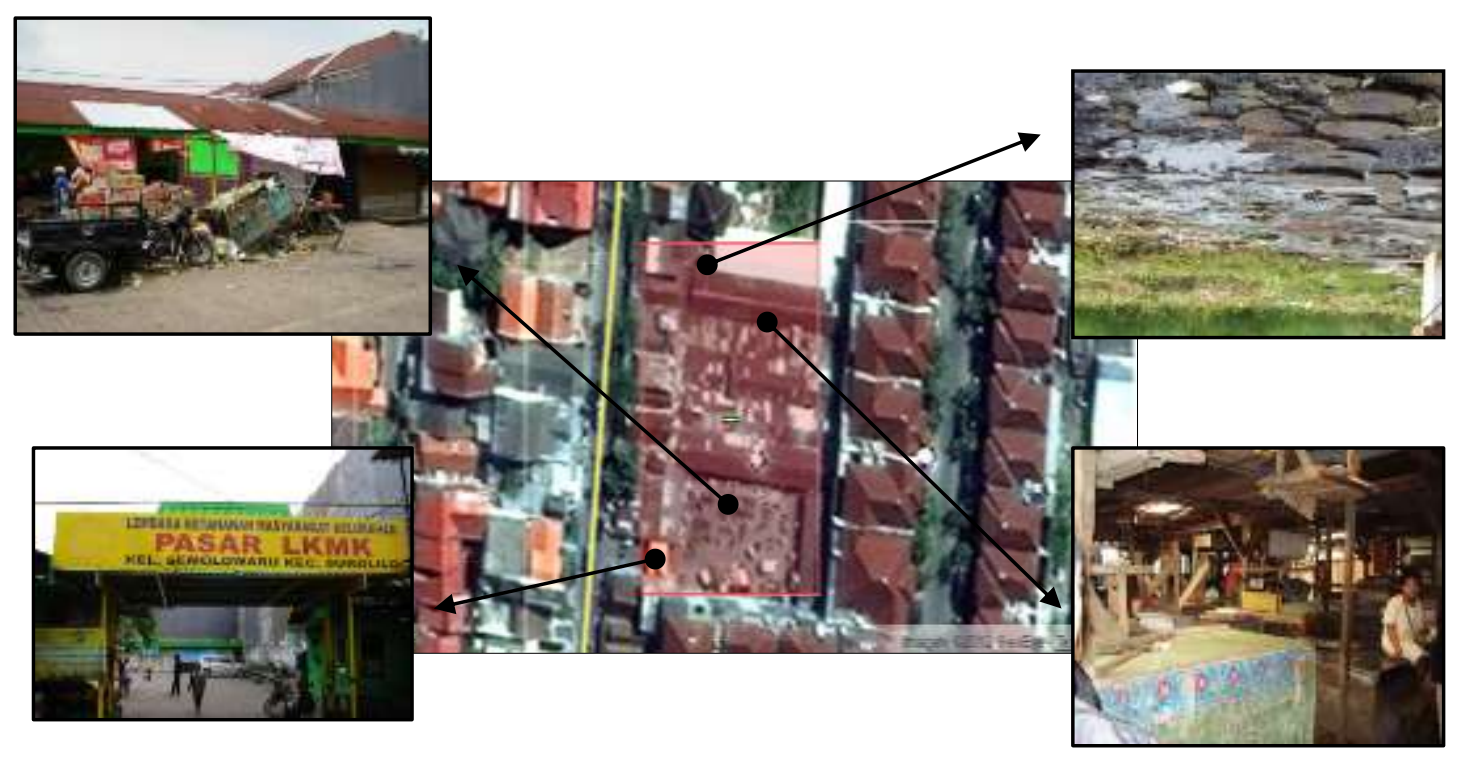

Gambar 2. Eksisting pasar LKMK Semolowaru 
Menurut Peraturan Presiden RI Nomor 12 tahun 2007 tentang Penataan Dan Pembinaan Pasar Tradisional, Pusat Perbelanjaan, Dan Toko Modern, pasal 1, yang dimaksud dengan Pasar tradisional adalah pasar yang dibangun dan dikelola oleh Pemerintah, Pemerintah Daerah, Swasta, Badan Usaha Milik Negara dan Badan Usaha Milik Daerah termasuk kerjasama dengan swasta dengan tempat usaha berupa toko, kios, los dan tenda yang dimiliki/dikelola oleh pedagang kecil, menengah, swadaya masyarakat atau koperasi dengan usaha skala kecil, modal kecil dan dengan proses jual beli barang dagangan melalui tawar menawar.
Pasar tradisional dengan konsep modern bukan berarti sama dengan supermarket atau swalayan, jadi sistemnya masih tetap sama dengan pasar tradisional, namun bangunannya yang didesain dengan konsep modern. Pasar Modern ini akan menghasilkan pasar tradisional yang terkesan bersih dan tidak berbau seperti halnya di pasar tradisional, tidak becek dan tidak kumuh. Pembeli dan penjual masih tetap dapat berjumpa dan melakukan tawarmenawar ataupun bersilaturahmi, kelebihan dari konsep pasar tradisional adalah ikatan penjual di pasar tradisional sangat erat dengan pelanggannya. Sistem drainasenya ditata dengan baik, kemudian didesain agar pemeliharaannya juga mudah.

Tabel 1. Perbandingan pasar tradisional dan pasar modern

\begin{tabular}{|c|c|c|}
\hline Variabel & Pasar Tradisional & Pasar Modern \\
\hline Price & $\begin{array}{l}\text { Harga lebih murah } \\
\text { Harga bisa ditawar }\end{array}$ & Harga pasti \\
\hline Product & $\begin{array}{l}\text { Menyediakan produk lebih segar } \\
\text { Menawarkan beragam produk segar } \\
\text { Menyediakan segala yang diperlukan }\end{array}$ & Kebersihan produk terjamin \\
\hline Place & Lokasi dekat dengan rumah & $\begin{array}{l}\text { Bersih } \\
\text { Fasilitas lengkap }\end{array}$ \\
\hline Service & $\begin{array}{l}\text { Suasana yang hidup dan Ramai } \\
\text { Buka dari pagi hari } \\
\text { Pembeli dalam jumlah yang fleksibel }\end{array}$ & $\begin{array}{l}\text { Aman } \\
\text { Disediakan kantong belanja }\end{array}$ \\
\hline
\end{tabular}

Sumber : Hasil Penelitian AC Nielsen, 2004

Konsep perancangan pasar modern menggunakan elemen - elemen sebagai berikut : peruntukan lahan (mikro dan makro), intensitas bangunan pasar, system penghubung antar ruang dalam pasar, aktivitas pendukung, dan pembagian ruang pasar.

Tujuan yang ingin dicapai dalam penelitian ini adalah untuk membuat konsep penataan ruang pasar tradisional dengan konsep modern di Pasar LKMK Semolowaru Surabaya dengan tidak mengubah konsep dari pasar tradisionalnya. Tujuannya dari penelitian ini adalah :

1) Melakukan penataan terhadap los dan kios pasar

2) Merencanakan bangunan pasar yang refresentatif, bersih dan nyaman yang dapat dikunjungi oleh semua orang tanpa melihat umur.

3) Membuat konsep yang modern pasar LKMK Semolowaru
Manfaat yang akan dihasilkan adalah melestarikan karakteristik pasar tradisional menjadi salah satu penunjang perekonomian masyarakat dan tetap terjalinnya silahturahmi antar pedagang dan pembeli dalam tawar menawar harga.

\section{METODOLOGI PENELITIAN}

Rancangan penelitian menggunakan penelitian Deskriptif kualitatif yang bersifat menjelaskan (explanatory research) dengan pendekatan problem sholving approach. Variabel dari penelitian ini ada 3 yaitu : karakteristik pedagang dan pembeli, aktivitas pasar dan ruang pasar. Populasi adalah para pedagang dan pembeli yang bertransaksi di areal pasar tradisional LKMK Semolowaru sehingga sampel yang digunakan sebesar 96 orang sudah termasuk pedagang dan pembeli di dalam areal pasar semolowaru. Metode pengumpulan data dibedakan berdasarkan jenis data yaitu data primer 
dengan cara observasi, wawancara, penyebaran quisioner dan dokumentasi sedangkan untuk data sekunder adalah dengan studi literature. Dalam penelitian ini analisis yang digunakan adalah analisis deskriptif kualitatif. Potensi - potensi yang akan dianalisis adalah analisis karakteristik pedagang dan pembeli, analisis aktivitas pasar, dan analisis ruang pasar. Secara detail proses penelitian yang dilakukan dapat dilihat pada tabel berikut :

Tabel 2. Definisi operasional variabel

\begin{tabular}{|c|c|c|c|c|c|c|}
\hline $\begin{array}{l}\mathbf{N} \\
\mathbf{O}\end{array}$ & Sasaran & $\begin{array}{l}\text { Variabel } \\
\text { Amatan }\end{array}$ & Data & Sumber & Survey & Analisa \\
\hline \multirow[t]{5}{*}{1.} & \multirow{5}{*}{$\begin{array}{l}\text { Mengidentifi } \\
\text { kasi } \\
\text { karakteristik } \\
\text { pedagang } \\
\text { Pasar LKMK } \\
\text { Semolowaru }\end{array}$} & $\begin{array}{l}\text { Asal } \\
\text { pedagang }\end{array}$ & Data asal pedagang & Wawancara & Primer & \multirow[t]{5}{*}{$\begin{array}{l}\text { Analisa } \\
\text { karakteistik } \\
\text { pedagang }\end{array}$} \\
\hline & & $\begin{array}{l}\text { Alasan } \\
\text { Berdagang }\end{array}$ & $\begin{array}{ll}\text { Data } & \text { alasan } \\
\text { berdagang }\end{array}$ & Wawancara & Primer & \\
\hline & & $\begin{array}{l}\text { Tingkat } \\
\text { pendidikan }\end{array}$ & $\begin{array}{l}\text { Data tingkat } \\
\text { pendidikan }\end{array}$ & Wawancara & Primer & \\
\hline & & $\begin{array}{l}\text { Frekuensi } \\
\text { berdagang }\end{array}$ & $\begin{array}{ll}\begin{array}{l}\text { Data } \\
\text { berdagang }\end{array} & \text { frekuensi } \\
\end{array}$ & Wawancara & Primer & \\
\hline & & $\begin{array}{l}\text { Motivasi } \\
\text { pedagang }\end{array}$ & $\begin{array}{l}\text { Motivasi berdagang } \\
\text { karena turun temurun, } \\
\text { tuntuan hidup, atau } \\
\text { keahlian }\end{array}$ & Wawancara & Primer & \\
\hline \multirow[t]{3}{*}{2.} & \multirow{3}{*}{$\begin{array}{l}\text { Mengidentifi } \\
\text { kasi aktivitas } \\
\text { pasar dan } \\
\text { pedagang } \\
\text { Pasar LKMK } \\
\text { Semolowaru }\end{array}$} & Rotasi pasar & $\begin{array}{l}\text { Pergantian waktu } \\
\text { aktivitas pasar }\end{array}$ & $\begin{array}{l}\text { Observasi } \\
\text { dan } \\
\text { Wawancara }\end{array}$ & Primer & \multirow{3}{*}{$\begin{array}{l}\text { Analisa } \\
\text { aktivitas } \\
\text { pasar dan } \\
\text { pedagang }\end{array}$} \\
\hline & & $\begin{array}{l}\text { Arus barang } \\
\text { dan jasa }\end{array}$ & $\begin{array}{l}\text { Data aktivitas arus } \\
\text { barang dan jasa }\end{array}$ & Wawancara & Primer & \\
\hline & & $\begin{array}{l}\text { Tingkat } \\
\text { persaingan } \\
\text { pedagang }\end{array}$ & Data aktivitas pasar & Wawancara & Primer & \\
\hline \multirow[t]{5}{*}{3.} & \multirow{5}{*}{$\begin{array}{l}\text { Mengidentifi } \\
\text { kasi ruang } \\
\text { yang } \\
\text { terbentuk } \\
\text { akibat } \\
\text { pemanfaata } \\
\mathrm{n} \text { ruang } \\
\text { pedagang } \\
\text { pasar } \\
\text { tradisional }\end{array}$} & $\begin{array}{l}\text { Peruntukan } \\
\text { Lahan }\end{array}$ & Peta lokasi & Observasi & Primer & \multirow{5}{*}{$\begin{array}{l}\text { Analisa } \\
\text { ruang pasar } \\
\text { tradisional }\end{array}$} \\
\hline & & Intensitas & Peta lokasi & Dinas Pasar & Sekunder & \\
\hline & & $\begin{array}{l}\text { System } \\
\text { penghubung } \\
\text { ruang }\end{array}$ & Peta lokasi & $\begin{array}{l}\text { Observasi } \\
\text { dan } \\
\text { wawancara, } \\
\text { dinas pasar }\end{array}$ & $\begin{array}{l}\text { Primer dan } \\
\text { sekunder }\end{array}$ & \\
\hline & & $\begin{array}{l}\text { Aktivitas } \\
\text { pendukung }\end{array}$ & Data aktivitas pasar & $\begin{array}{l}\text { Observasi } \\
\text { dan } \\
\text { wawancara, } \\
\text { dinas pasar }\end{array}$ & $\begin{array}{l}\text { Primer dan } \\
\text { sekunder }\end{array}$ & \\
\hline & & Dimensi ruang & Peta lokasi & observasi & Primer & \\
\hline \multirow[t]{3}{*}{4.} & \multirow{3}{*}{$\begin{array}{l}\text { Konsep } \\
\text { penataan } \\
\text { ruang pasar } \\
\text { LKMK } \\
\text { Semolowaru }\end{array}$} & $\begin{array}{l}\text { Karakteristik } \\
\text { pedagang }\end{array}$ & $\begin{array}{l}\text { Data karakteristik } \\
\text { pedagang }\end{array}$ & Wawancara & Primer & \multirow{3}{*}{$\begin{array}{l}\text { Analisa } \\
\text { penataan } \\
\text { ruang pasar } \\
\text { LKMK } \\
\text { Semolowaru }\end{array}$} \\
\hline & & $\begin{array}{l}\text { aktivitas pasar } \\
\text { dan pedagang }\end{array}$ & $\begin{array}{l}\text { Data karakter } \\
\text { aktivitas pasar dan } \\
\text { pedagang }\end{array}$ & Wawancara & Primer & \\
\hline & & $\begin{array}{l}\text { Ruang pasar } \\
\text { yang } \\
\text { digunakan }\end{array}$ & $\begin{array}{l}\text { Data ruang pasar } \\
\text { yang digunakan }\end{array}$ & Wawancara & Primer & \\
\hline
\end{tabular}

Sumber : hasil kajian

HASIL PENELITIAN

Hasil penelitian ini menggunakan beberapa variable yang sudah di tentukan pada ruang lingkup materi sehingga menghasilkan beberapa ulasan sebagai berikut : 
1. Hasil analisis karakteristik pedagang dan pembeli

\section{a. Pedagang}

Asal pedagang sebagian besar berasal dari kelurahan Semolowaru dengan pendidikan lulusan Sekolah Menengah atas. Alasan berdagang yang mereka kemukakan sangat beragam tetapi sebagian besar dari mereka beralasan karena tuntutan ekonomi. Untuk itu mempengaruhi motivasi mereka untuk semangat berdagang sangat tinggi.

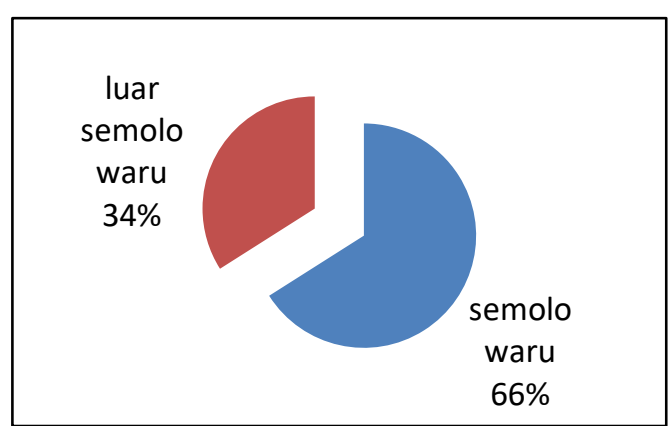

Gambar 1. Asal Pedagang

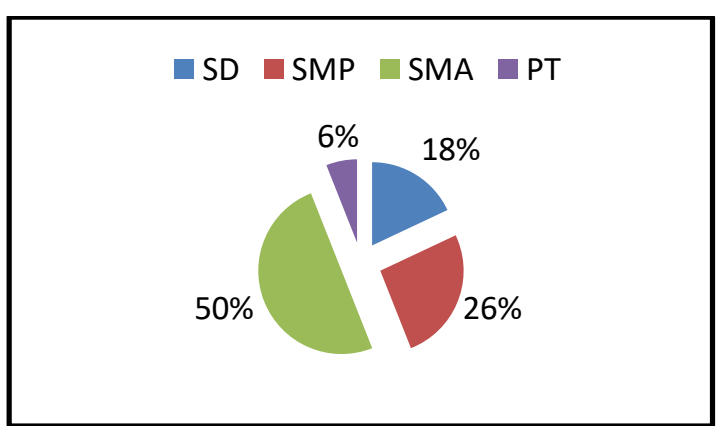

Gambar 2. Pendidikan Pedagang

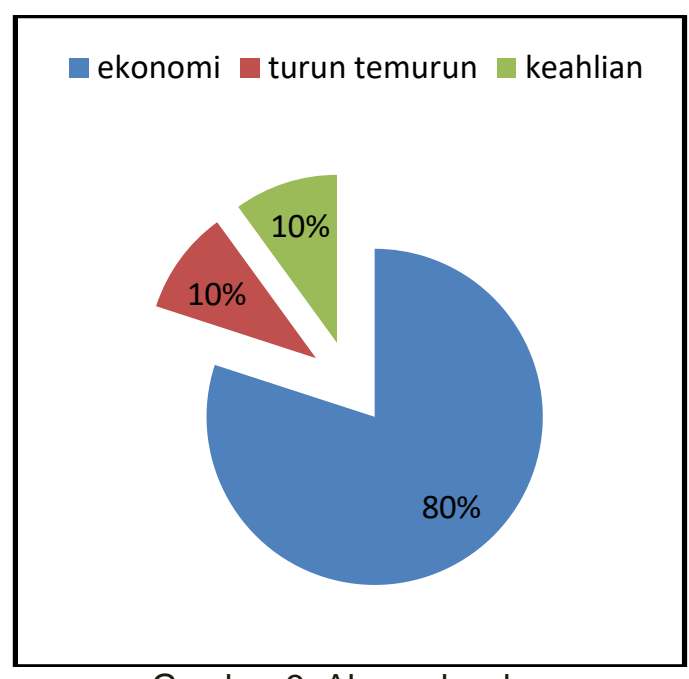

Gambar 3. Alasan berdagang

\section{b. Pembeli}

Asal pembeli sebagian besar berasal dari Kelurahan Semolowaru. Frekuensi pembeli pergi ke pasar tradisional semolowaru sebagian besar mengatakan hampir setiap hari mereka berbelanja keperluan sehari hari di pasar semolowaru dengan alasan karena jenis dagangan yang diperjual belikan beraneka ragam

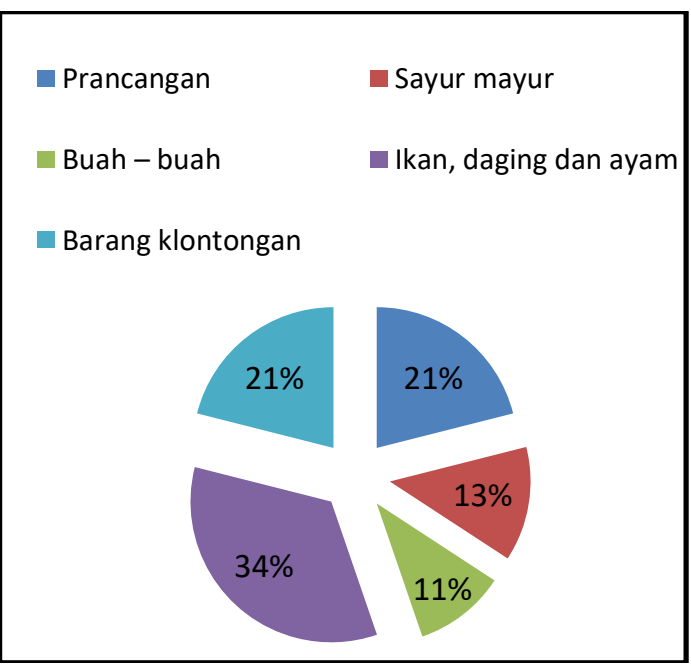

Gambar 4. Jenis Barang Yang Dijual

serta harganya yang relative murah dan juga pelayanan para pedagang yang ramah. Sebagian besar dari pembeli fasilitas utama dan pedukung pasar karena tidak terawatt dengan baik. Untuk pendamping pergi ke pasar banyak ibu - ibu yang diantar oleh anak - anak. Hal ini diperlukan untuk mencari aktivitas pendukung pasar yang banyak diminati. 


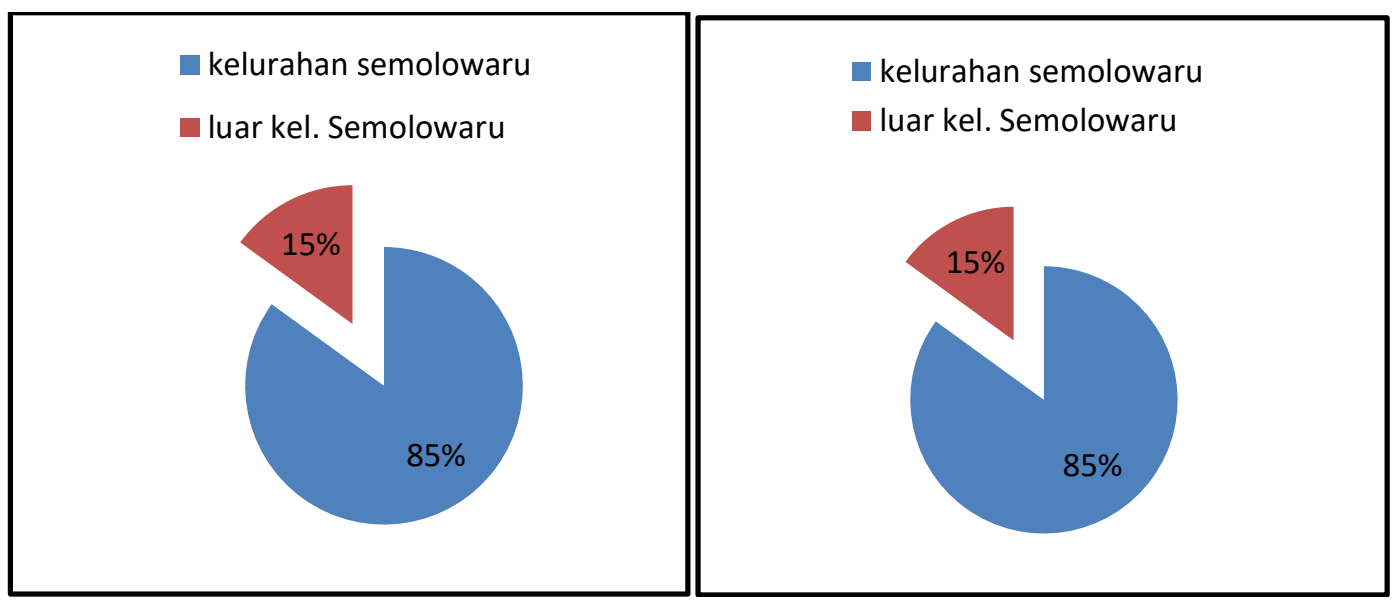

Gambar 5. Asal Pembeli

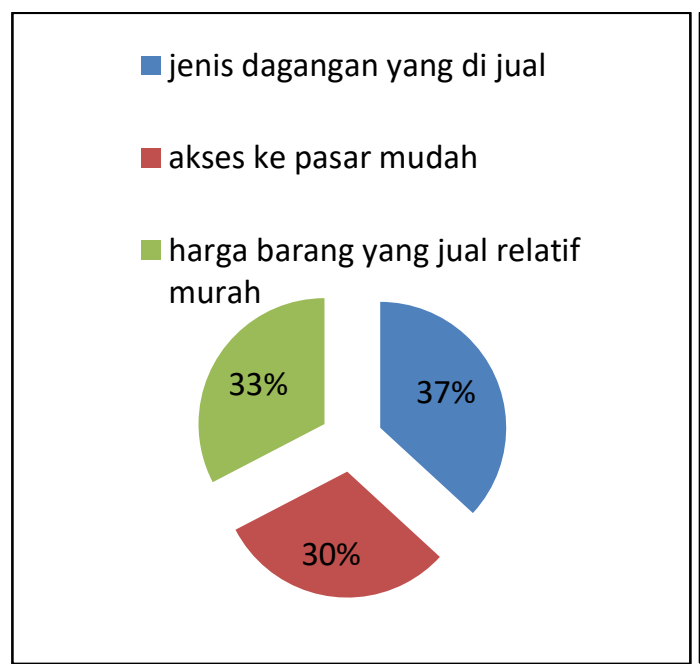

Gambar 7. Alasan Pergi ke Pasar
Gambar 6. Frekuensi pergi ke pasar

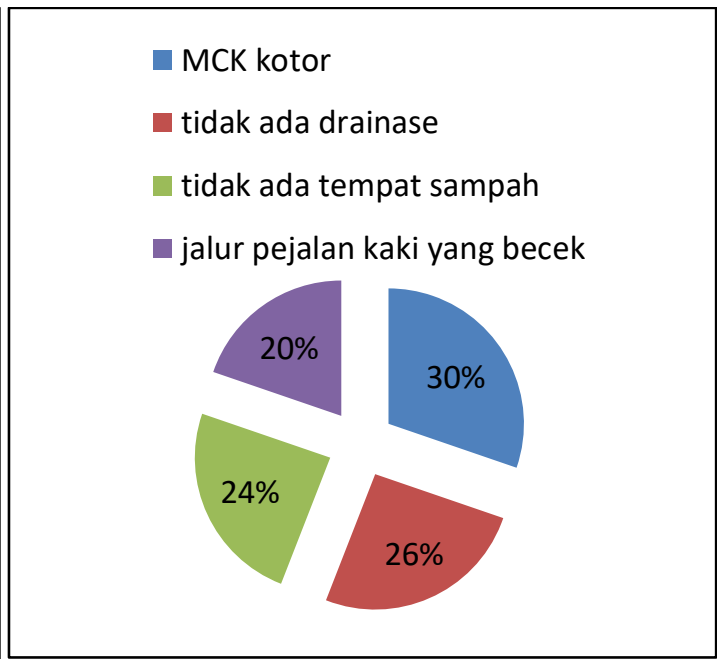

Gambar 8. Fasilitas Yang Perlu di Perbaiki

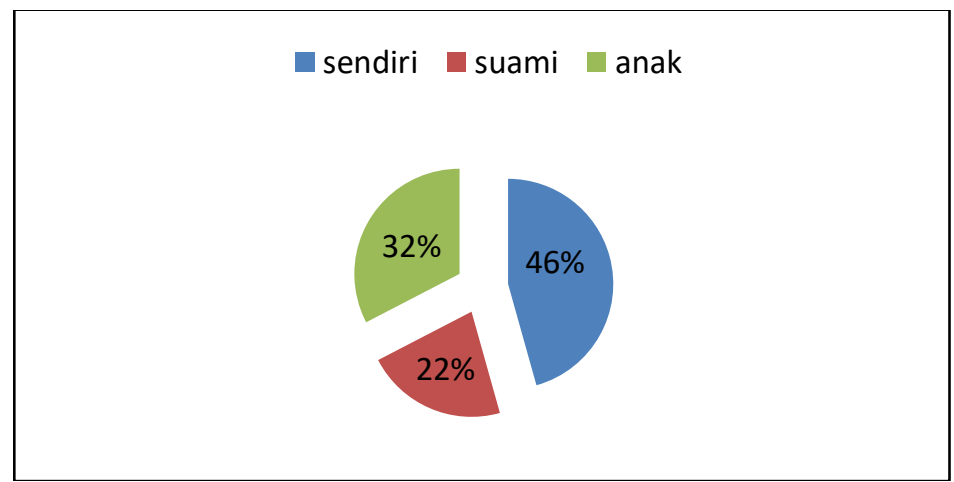

Gambar 9. Pendamping Saat Pergi ke Pasar

\section{Hasil analisis aktivitas pasar}

\section{a. Rotasi pasar}

Rotasi pasar yang terjadi di pasar hanya dua kali aktivitas pagi sampai siang dan aktivitas siang sampai sore. Hal ini menyebabkan kurang maksimal penggunaan waktu dan ruang di pasar tradisional Semolowaru. Waktu sore sampai pagi tidak ada aktivitas apa - apa sehingga ruang yang ada di pasar tidak digunakan.

b. Arus barang dan jasa

Pasar dikatakan baik jika kegiatan distribusi barang dan jasa dari produsen ke komsumen berjalan lancar. Barang yang diperjual belikan di pasar tradisional semolowaru berasal dari kawasan sekitar 
Surabaya dan sidoarjo. Kegiatan bongkar muat dimulai pukul 04.30 dini hari sehingga tidak mengganggu pembeli. Jika dilihat dari arus barang dan jasan menunjukkan bahwa sebagian besar para pedagang menjual hasil dagangnya langsung ke komsumen dan sebagian kecil ke pedagang pengecer.

c. Tingkat persaingan pedagang Tingkat persaingan pedagang rendah karena masih ada saling kerjasama antar pedagang untuk meminjam barang dari pedagang lainya. Hal ini dikarena jenis barang yang dijual sangat beraneka ragam dengan jumlah yang sedikit.

\section{Hasil analisis ruang pasar}

a. Fasilitas Perdagangan

Fasilitas perdagangan berupa toko, kios dan los. Fasilitas toko perlu penambahan ruang untuk bangunan toko yang tidak sesuai dengan standar minimum bangunan toko, sedangkan untuk perkerasan lantai dan arah sudah sesuai dengan standar. Fasilitas kios perlu melakukan renovasi pada dinding dan lantai kios yang sudah lapuk dan banyak lubang. Fasilitas los sudah sesuai dengan standar hanya perlu di lakukan pemerataan dalam pembagian jenis barang dagangan dan pembagian jumlah los.

b. Fasilitas Pendukung

Fasilitas pendukung berupa Musholah, MCK, areal parkir dan areal bongkat muat. Fasilitas pendukung Musholah perlu adanya drainase untuk aliran pembuangan limbah sisa wudhi maupun air hujan. Fasilitas MCK perlu dilakukan pemindahan lokasi karena sangat berdekatan dengan areal suci Musholah dan pembuatan sanitasi pembuangan limbahnya. Fasilitas areal parkir tidak banyak berubah karena sudah sesuai dengan standar. Fasilitas areal bongkar muat perlu adanya ruang untuk digunakan sebagai kegiatan bongkar muat barang dan jasa tetapi hal ini tidak memungkinkan karena areal yang tersedia terbatas. Oleh karena itu yang bisa dikembangkan adalah pembagian waktu aktivitas bongkar muat barang dilakukan sebelum aktivitas pasar dimulai. Setelah itu tidak diijinkan untuk melakukan aktivitas bongkar muat barang dan jasa.

c. Sirkulasi Pasar

Hasil analisis sirkulasi pasar adalah memperlebar pintu masuk dan keluar dari pasar Semolowaru dengan membedakan elevasi antar pengguna jalan yaitu pejalan kaki dan pengguna kendaraan bermotor. Hal ini dikarenakan keterbatasan lahan dan kepadatan penduduk disekitar areal pasar tradisional semolowaru.

d. Pedestrian way

Analisis pedestrian way dengan melihat kondisi fasilitas pendukung dan sirkulasi pasar maka perlu pembagian antar pengguna kendaraan bermotor dan orang di pintu masuk keluar pasar. Dan juga memperbaiki jalan - jalan yang memisahkan kios, toko dan los yang menjadi lokasi pengikat kegiatan pasar dengan perkerasan paving blok yang lebih tertata dan juga perbedaan elevasi antara kegiatan kendaraan bermotor dengan pejalan kaki.

e. Ruang Terbuka

Analisis ruang terbuka di belakang atau disebelah utara pasar dengan berdasarkan karakteristik pembeli, intensitas dan rotasi kegiatan pasar dan juga kondisi fasilitas pendukung pasar, maka penggunaan ruang terbuka selain sebagai taman hijau untuk penyerapan air hujan juga penambahan tempat untuk bank sampah, ruang bermain, fasilitas pendukung MCK dan ruang baca. Sehingga terjadi konektivitas antara kegiatan utama pasar dengan ketgiatan pendukung pasar.

f. Aktivitas Pendukung

Analisis pendukung dengan melihat karakteristik pedamping pembeli saat pergi kepasar. Intensitas kegiatan di luar pasar dan rotasi pasar. Dari variable itu dapat dianalisis maka mendukung karakteristik pendamping pembeli saat pergi ke pasar adalah mulai dari bapak baka sampai dengan anak - anak maka untuk mendukung kehadiran mereka di ruang kosong akan dirancang ruang baca dan ruang bermain.

\section{PEMBAHASAN}

Karakteristik Pedagang dan Pembeli pasar LKMK Semolowaru sebagian besar berasal dari kelurahan Semolowaru dengan frekuensi yang rutin setiap hari melakukan transaksi di pasar. Sebagian dari pembeli membawa anaknya untuk menemani pergi 
kepasar, sehingga menjadi landasan untuk menempatkan suatu tempat atau ruang lain sebagai aktivitas penunjang. Untuk fasilitas pasar yang perlu diperbaiki, $30 \%$ responden menyatakan toilet karena tempatnya di belakang pasar, tidak ada perkerasan dan juga tidak ada drainase untuk pembuangan limbahnya sehingga terkesan becek, bau dan kotor. Untuk itu landasan desain yang akan dilakukan adalah dengan membuat toilet yang bersih dan nyaman dilengkapi dengan saluran drainase.

Aktivitas pasar yang terdiri dari rotasi pasar, arus barang dan Jasa, dan tingkat persaingan para pedagang dipasar LKMK Semolowaru menjadi landasan desain penataan pasar untuk bias menjadi lebih optimal. Rotasi pasar tidak hanya berlangsung pagi hari saja, pada sore hari bias di optimalkan sebagai sentra makanan / tempat PKL untuk berdagang sehingga bias menambah pendapatan dari dana sewa dan tempat parker. Tingkat persaingan antar pedagang sangat rendah, hal ini terlihat dari harga yang ditawarkan, antara pedangan satu dengan pedagang lain harga yang ditawarkan hamper sama, bahkan terjadi kerjasama dengan saling menjualkan barang dari pedagang lain jika kehabisan. Konsep pasar tradisional yang seperti ini yang tidak ada di pasar modern.

Pemanfaatan ruang pasar untuk fasilitas utama perdagangan ada beberapa rekomendasi seperti ukuran toko dan kondisi bangunan kios dan los. Sebagai system penghubungnya berupa jalan pedestrian diperbaiki dengan menggunakan perkerasan paving blok.

Fasilitas pendukung seperti MCK musholah dan saluran drainase terjadi perubahan. Untuk lokasi MCK dipindahkan berada di belakang musholah sehingga antara aktivitas umum dengan kegiatan keagamaan tidak tercampur, sehingga nuansa rohani bisa dimunculkan. Ditambahkan lagi bangunan gudang yang bisa digunakan oleh pengelolah pasar untuk menyimpan barang inventarisasi pasar. Musholah tetap hanya tempat wudhu lebih di perbesar dimensinya.

Untuk sampah yang dihasilkan oleh pasar, menggunakan ruang kosong sebagai depo atau bank sampah sehingga penempatan gerobak sampah tidak lagi menghabiskan areal parkir dan juga penghilangkan pemandangan dan juga bau sampah yang tidak sedap. Pendistribudian sampah yang telah terkumpul dilakukan pada sore hari pada saat kegiatan pasar sudah tutup dan kegiatan sentra makanan belum mulai.

Dari karakteristik pedagang dan pembeli, aktivitas pasar dan juga ruang pasar, maka hasil penelitian berupa desain perencanaan dan penataan ruang pasar LKMK Semolowaru yang akan di jabarkan di bawah ini.

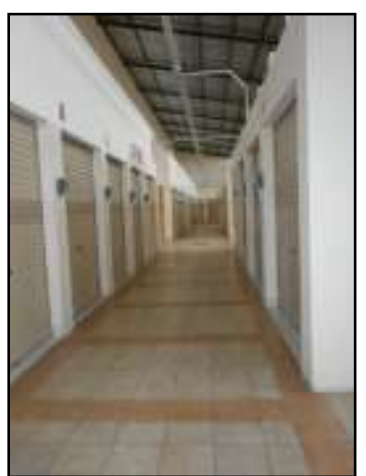

Gambar 3. Desain toko dan kios pasar

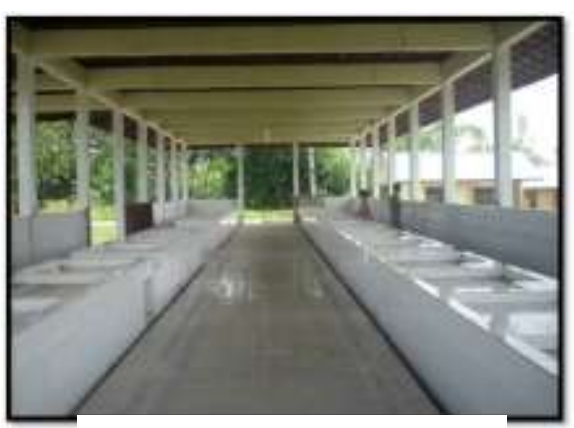

Gambar 4. Desain los pasar

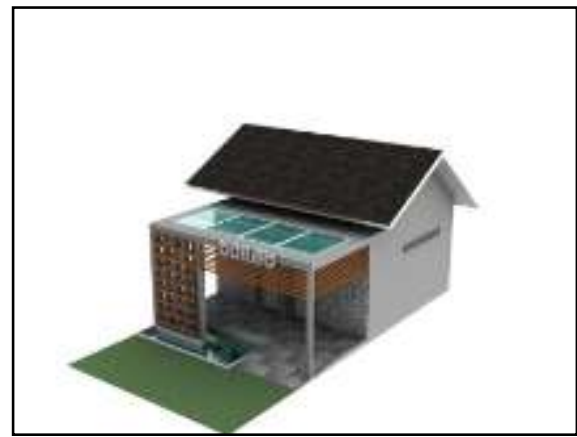

Gambar 5. Desain toilet pasar 


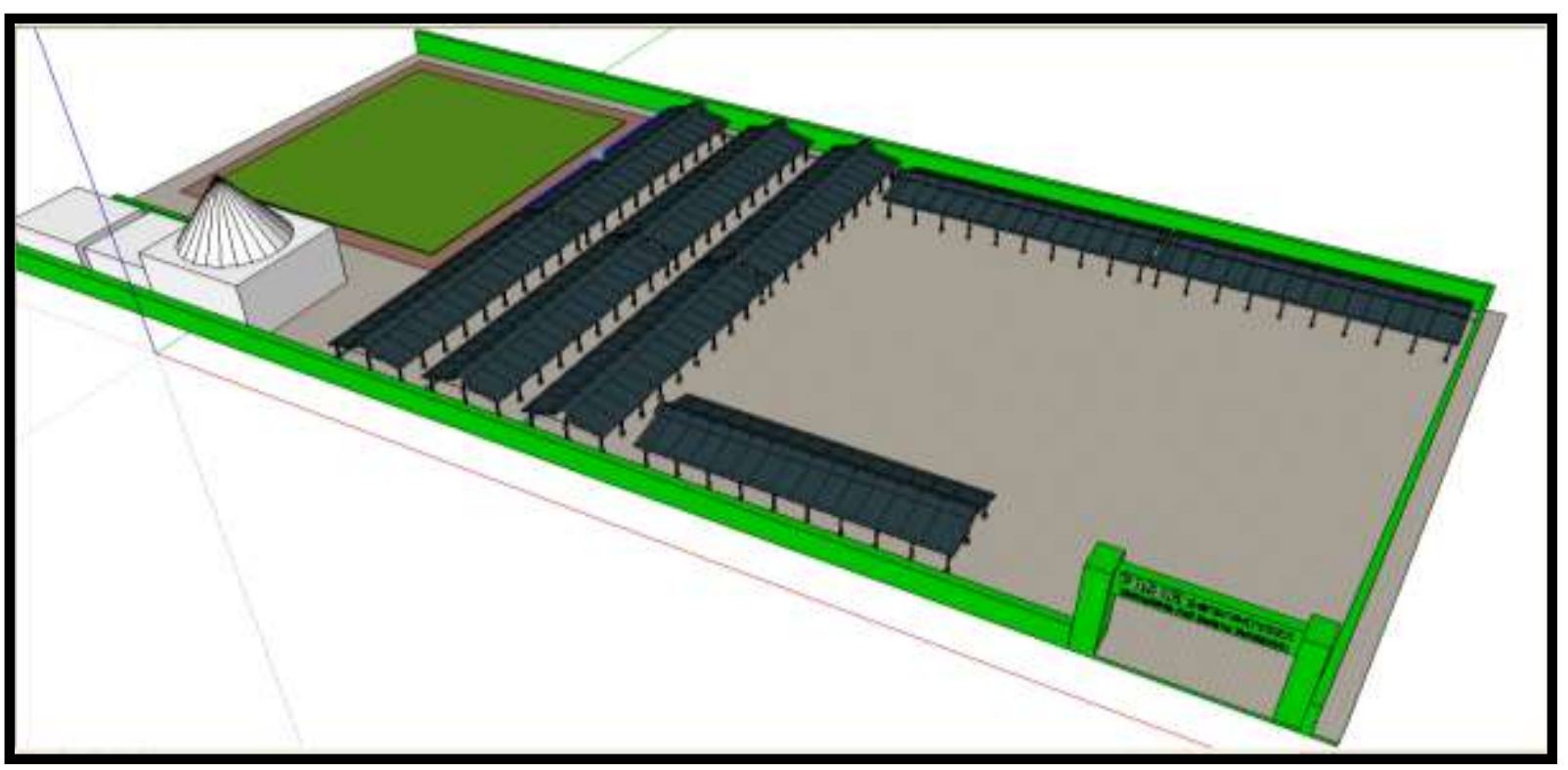

Gambar 6. Perencanaan penataan pasar LKMK

Semolowaru

\section{KESIMPULAN DAN REKOMENDASI}

1. Kesimpulan

a. Karakteristik pedagang dan pembeli Sebagian besar merupakan masyarakat Kelurahan Semolwoaru dan sekitarnya. Sehingga menjadi peluang besar dapat lebih mengembangkan lagi pasar semolowaru agar menjadi jujukan masyarakat skala kecamatan dan bahkan kabupaten.

b. Aktivitas pasar

Aktivitas pasar hanya ramai pada pagi hari sedangkan siang sampai sore tidak ada aktivitas. Perlu aktivitas lain untuk mendukung keberadaan pasar semolowaru seperti penempatan sentra makanan dan pembentukan bank sampah di areal dalam pasar LKMK Semolowaru.
C. Ruang pasar

1) Pemanfaatan ruang pasar belum optimal.

2) Perbaikan fasilitas utama dan pendukung perdagangan

3) Pintu masuk keluar pasar perlu pemisahan antara pejalan kaki dan kendaraan bermotor.

4) Perlu pemanfaatan kemiringan tanah untuk pembuatan saluran drainase

2. Rekomendasi

a. Penataan pasar tradisional LKMK semolowaru dengan konsep Modern.

b. Pendanaan : Kas LKMK dan Bantuan dana dari Kelurahan Semolowaru juga kecamatan Sukolilo.

c. Pemanfaatan ruang pasar yang bisa meningkatkan aktivitas pasar merelokasi pedagang kaki lima

d. Bekerja sama dengan Dinas - dinas terkait 


\section{DAFTAR PUSTAKA}

Bakri Masykuri, 2003. Metodologi Penelitian Kualitatif - Tinjaun Teoritis dan Praktis. Lembaga Penelitian Universitas Malang-Visipres, Surabaya.

Bungin,Burhan, 2001. Metodologi Penelitian Sosial : Format-format Kuantitatif dan Kualitatif. Airlangga University Press, Surabaya.

Erlangga, 2008. IImu Pengetahuan Sosial. Kelas VIII, Bab 9, Jakarta.

Erlangga, 2006. IPS SMP/MTs. Kelas VIII, Bab 10, Jakarta.

Shirvani Hamid, Urban Design Process, Van Nostrand Reindhold Bo New York 1985

Arrosyadi, 2010, Pengertian Konsep, website www. arrosyadi.wordpress.com

Arum, 2006, Pendidikan Karakter, website www.arum7p.multiply.com

Ensiklopedi Bebas, 2009, Bahasa Indonesia, website www.Wikipedia.org

Harian Kompas, 2007, Krisis Pasar Tradisional, website www.Kompas.com

Kerja Sama antara INDEF dan Departemen Perdagangan RI, 2007, Ringkasan Eksekutif, "Kajian

Dampak Ekonomi Keberadaan Hypermarket terhadap Ritel/Pasar Tradisional", website www.indef.or.id

Rudy, 2006, Pasar Tradisional vs Pasar Modern, Jakarta, website www.hilmiarifin.com

Sumijanto, 1992, Surabaya Post, website www.petra.ac.id

Tim IWPL-Perdagangan Direktorat Jenderal Dalam Negeri Departemen Perindustrian dan Perdagangan RI, 1996, Kajian Tentang Profil Pasar/Pemetaan Pasar, Jakarta, website www.openlibrary.org

http://www.arsiteka.com/2010/08/desain-pasar-modern-kalisat-jember.html 